\title{
COMMUNICATION
}

Science EO Society, Vol. 81, No. 3, July 2017, 427-436

\section{CARCHEDI'S DIALECTICS: A CRITIQUE}

Several years ago Guglielmo Carchedi $(2008 ; 2012)$ published in SES two interesting pieces on Marx's dialectics and mathematics. His basic aim was to discover whether Marx's Mathematical Manuscripts provide a new insight into Marx's dialectics. The reading he suggested was addressed to Marx alone, i.e., without Hegel and Engels. This, he argued, is the only way to grasp Marx's dialectics if one wants to understand Marx in his own terms. Since Marx never explicated his notion of dialectics, we ought to derive it from Marx's own work. To this end, Carchedi first defined "dialectics as a method of social research" (Carchedi, 2008, 416), and then listed three principles of dialectics: 1) "all phenomena are always both realized and potential"; 2) "they are always both determinant and determined"; 3) they are "always subject to movement and change" (ibid.). Later he added a fourth principle: 4) "social phenomena's movement (change) is tendential" (Carchedi, 2012, 547). He emphasized that these principles are limited to society and not to be confused with nature, because society, unlike nature, necessarily involves "human volition and consciousness" (ibid.). For this reason, "Engels' dialectics of nature cannot be applied to society" (ibid.), a claim he also asserted in his book Behind the Crisis (2011, 37-8).

Given the long history of Engels criticism, Carchedi seems to follow an old pattern by distinguishing Marx's social science from Engels' naturephilosophical enterprise. What is unique about Carchedi's approach is that, to my knowledge, no one has attempted before to bridge the divide between dialectics and mathematics in Marx by eliminating Engels' dialectics of nature. 
I will divide this Communication into two sections. In the first section, I will first argue that Carchedi's approach runs into some difficulties, for Marx made explicit references to Hegel's dialectics in Capital and elsewhere, and much of what stands and falls with Marx's dialectics is a product of Marx and Engels' close collaboration. I will also show some unmistakable similarities between Carchedi's principles and Engels' dialectics. I will conclude that Carchedi's dialectics is closer to that of Engels than Carchedi thinks it is. In the second section, I will focus on a particular example of Engels' dialectics, i.e., planetary motion, a detail which Russell Dale (2011, 563-4) mentions in his comment on Carchedi. However, what Dale does not mention is that Marx, I claim, indirectly refers to planetary motion in Capital, and calls it a "contradiction" (Marx, 1983, 65).

I assume that Carchedi would agree with me that we can speak of dialectics of nature in Engels' sense of the term, if Marx calls planetary motion a contradiction (see also Weston, 2012,4). Since Marx does not mention planetary but elliptical motion, we need to examine whether Marx intended to mean planetary motion by the "ellipse" figure (Marx, 1983, 65). This requires an investigation into Marx's familiarity with the motion of planets and its feasible connections with his economic studies. I will try to show that the ellipse case is also helpful to understand how and why Marx came to study mathematics in the first place. My thesis is that Marx studied astronomy in general and elliptical motion of planets in particular to a great extent, and utilized astronomic mathematics for economic-scientific purposes. This will also lead us to ask whether Marx adopted a dialectics of nature by involving the notion of contradiction in planetary motion in Hegel's and Engels' sense of the term.

\section{Carchedi's Theoretic Patterns}

It was probably Lukács $(1977,175)$ who first proposed to remove Engels' dialectics of nature from Marx's scientific research. He wrote in the early 1920s that Engels was mistaken in his attempt to apply the interrelation of subject and object, theory and practice, logic and history to a dialectics of nature. ${ }^{1}$ In a similar fashion, Sartre $(2004,27)$ impugns Engels' enterprise because the latter "presents the dialectic, a priori and without justification, as the fundamental law." A "mere ordering of the facts" was an "abortive" initiation peculiar to a non-Marxist materialism. Lichtheim $(1972,212)$ claims that Engels' theory did not find support in Marx. It was rather "an eclectic

1 In his 1925 defense, Lukács $(1998 / 99,127-8)$ controversially claimed that he did not refer to nature but to knowledge of nature. In the late 1960s he admitted his earlier error and openly adopted Engels' dialectics of nature (Lukács, 1984, 395-6). 
composite of Marx's naturalism, Hegel's logic and contemporary positivism." Jordan (1967, 292-3) considers Engels to be a metaphysical materialist and contrasts him with Marx's anthropological-naturalistic approach. Avineri $(1975,65)$ stresses that Marx's materialism "differs sharply from the mechanistic materialism expounded by Engels.” Kołakowski (1978, 402-3) ascribes a "latent transcendentalism" to Engels, and a "dominant anthropocentrism" to Marx. Engels has criticized Hegel for the "non-dialectical conception of nature as repeating its cycle of evolution without a break," while Marx has assimilated Hegel by reversing his system and method upside-down. For Schmidt (1993, 55-6), Engels has sought to "interpret the area of pre- and extra-human nature in the sense of a purely objective dialectic" that lapsed into a "dogmatic metaphysic." Colletti $(1973,46)$ argues that Hegel's idea of totality "is clear and self-consistent"; in Engels, however, "it becomes pure nonsense."

If Carchedi claims that Engels' dialectics does not apply to society, then, I would say, he clearly belongs to this anti-Engels camp. Since Engels is also accused of following Hegel's mistaken lead in natural dialectics, and Marx was allegedly opposed to this view, one would be puzzled when facing an exchange between Marx and Engels in 1867, shortly before the publication of the first edition of Capital. As part of his research on dialectics of nature, Engels shares a few notes with Marx on the relation between quantity and quality, an aspect that he, Engels (1987b, 382), discovers when reading Hofmann's Introduction to Modern Chemistry. A "molecule as the smallest part of matter capable of independent existence," Engels writes, is "a perfectly rational category, a 'nodal point,' as Hegel calls it," which "marks a qualitative change." Marx (1987b, 385) believes that Engels is

quite right about Hofmann. Incidentally, you will also see from the conclusion of my Chapter III, where I outline the transformation of the master of a trade into a capitalist - as a result of purely quantitative changes - that in the text there I quote Hegel's discovery of the law of the transformation of a merely quantitative change into a qualitative one as being attested by history and natural science alike.

Marx $(1983,246 ; 1996,313)$ refers here to the following passage in Capital: "Here, as in natural science, is shown the correctness of the law discovered by Hegel (in his Logic), that merely quantitative differences beyond a certain point pass into qualitative changes." I wonder how Carchedi reads these lines. For he views Engels as being responsible for applying dialectics to nature. Following Carchedi, one could argue that Marx is no less guilty, because he not only shared Engels' contention but came to the same conclusion, independently of Engels, that there is a dialectics of nature. I suppose this is an example of what Carchedi $(2008,415)$ means by the "many inconsistencies" that one can find in Marx. 
What is more confusing is the similarity between Carchedi's four principles of dialectics and some passages in Engels' Dialectics of Nature. Surprisingly, Carchedi's first and third principles ("realized and potential," "movement and change") are cardinal principles which Engels (1987a, 333) has already adopted: "The indestructibility of motion cannot be conceived merely quantitatively; it must also be conceived qualitatively; matter whose purely mechanical change of place includes indeed the possibility under favorable conditions of being transformed into heat, electricity, chemical action, life." Carchedi's second principle ("determinant and determined") reminds me of Engels' observations on polar opposites: "polar opposites in general are determined by the mutual action of the two opposite poles on each other, that the separation and opposition of these poles exist only within their mutual connection and union" (ibid., 365). It is only Carchedi's fourth principle ("tendency") on which Engels did not write anything explicit in Dialectics of Nature. But Engels speaks of a reciprocal relation between the attraction force of a planetary central body (the Sun) and the tangential force driving the same planet away from the Sun (ibid.). They both are tendencies effecting an orbit's movement in opposite directions. In the next section I will argue that this relation between centripetal and tangential tendency is what Marx calls a contradiction.

\section{Marx on Elliptical Motion}

In the beginning of the chapter on "Metamorphosis of Commodities" in Capital, we read the following:

It is a contradiction, for example, for one body to continuously fall into another, and just as constantly fly away from it. The ellipse is one of the forms of movement in which this contradiction is actualized just as much as it is solved. (Marx, 1983, 65.) ${ }^{2}$

For Dale $(2011,563)$, elliptical motion of a planet is a "dialectically determined system," which is also "describable in terms of the same sophisticated modeling system of modern mathematics that is in question in Carchedi's article."

My basic concern is whether Marx meant planetary motion when using the "ellipse" figure. If the ellipse figure refers to planetary motion, which Marx calls a contradiction, then we can conclude that Marx had a concept of dialectics of nature. However, if Marx did not intend to mean planetary

2 "Es ist z. B. ein Widerspruch, daß ein Körper beständig in einen andern fällt und eben so beständig von ihm weg flieht. Die Ellipse ist eine der Bewegungsformen, worin dieser Widerspruch sich eben so sehr verwirklicht als löst." I borrow the English translation of this passage from Thomas Weston $(2012,5-6)$. 
motion and associates contradiction with something else, then his illustration is arbitrarily chosen and the ellipse case can be dropped.

Marx's physics and astronomy readings go back to his dissertation in the late 1830s and early 1840s (Marx, 1976a, 111-12). There is evidence that he was studying the theories of Kepler, Leibniz, Newton, and Hegel in the 1840 s and 1850s. When reading Newton's Principia, he noted: "Well said, old Isaak Newton" and "Bravo, old Newton!" (Kaiser and Werchan, 1967, 127). It is evident from a 1842 newspaper article that he was well-informed about the Leibniz-Newton controversy (Marx, 1975, 178). In The German Ideology, he claims that Newton "completed mechanics" (Marx, 1970, 49). In a 1853 column he mentions "the law of contact of extremes" which is related to "the laws of Kepler" and "Newton's great discovery" (Marx, 1984, 147). Two years before Capital's publication, Marx (1987b, 529-30) informs Engels that he “'took the opportunity' to 'take up' a little astronomy again." This time he was focused on "Laplace's theory of the formation of the celestial Systems and how he explains the rotation of the various bodies around their own axis." He also mentions that Laplace's theory has been further developed by an American astronomer, Daniel Kirkwood, who

discovered a kind of law concerning the difference in the rotation of the planets, which had previously appeared quite abnormal. . . . between two planets there must be a point at which their power of attraction is equally strong; so that a body at this point would remain stationary between them. . . . the body would fall towards one planet or another on either side of that point. This point thus forms the limits of the sphere of attraction of the planet. ... Kirkwood concluded from this that ... a specific relationship must exist between the velocity of the planet's rotation and the breadth of the ring from which it was formed or its sphere of attraction. . . . Old Hegel made some very good jokes about the "sudden reversal" of centripetal to centrifugal force, right at the moment when one has attained "preponderance" over the other; e.g., centripetal force is greatest near the sun; therefore, says Hegel, centrifugal force is greatest, since it overcomes this maximum of centripetal force and vice versa. Moreover, the forces are in equilibrium when half way between the apsides. Therefore they can never depart from this equilibrium. (Ibid.)

Marx is mainly concerned with the equilibrium dynamics of the elliptical motion of different orbits rotating around the Sun, that is, the reason why they do not fall into or fly away from the Sun. The aforementioned jokes of Hegel are related to his refusal of Newton's consideration of an orbit's tangential tendencies as forces. A passage in Capital shows that Marx was familiar with a popular idea widely circulated among many leading 19th-century astronomers: that a planet's rotative equilibrium would end by eventually hitting the Sun. He writes that capital is no more concerned with "coming degradation and final depopulation of the human race, as by the probable fall of the earth 
into the sun" (Marx, 1987a, 272-73). Regarding the apocalyptic collapse of Earth, we read something similar in Engels' Anti-Dühring (1988, 439):

The capitalist mode of production moves in these two appearance forms of the contradiction immanent to it from its very origin. It is never able to get out of that "vicious circle". . . . this circle is gradually narrowing; that the motion presents rather a spiral, and must reach to its end, like the motion of the planets, by collision with the center.

Some sources that were known both to Marx and Engels defend the apocalyptic collapse thesis. For instance, Helmholtz (1854, 38-9) believes that the ellipses of comets around the sun become "ever narrower," and "a time will come when the comet will strike the sun, and a similar end threatens all the planets"; "they must ... approach the sun." Mayer $(1874,171)$ argues that planetary bodies rotate "in ever narrower orbits around the sun and at last fall into it." Thomson and Tait $(1872,192)$ assert that the "effect of a continued tangential force ... is to gradually increase the distance from the central body, and to cause as much again as its own amount of work to be done against the attraction of the central mass, by the kinetic energy of motion lost."

All in all, what Marx (and Engels) read and wrote on elliptical motion gives us good reason to think that Marx's illustrative choice in Capital was not arbitrary, but a conscious and purposeful one. But why call it a contradiction? Note that Marx $(1983,481)$ views "the Hegelian "contradiction"” as "the source of all dialectics." Hegel $(1986,80)$ believes that there is a contradiction between gravitational force and all orbits that fall towards it. Gravitation "contradicts the law of inertia." The elliptical motion of orbits "is composed of this [gravitational] drive and of the tangential direction" (ibid., 83). What Hegel calls "tangential direction" or "diagonal" (ibid., 97) interacts with the gravitational force of the central body that results in the elliptical rotation of orbits.

Why is mathematics relevant to all this? Shortly after their exchange on Kirkwood, Marx sent a mathematical extract to Engels, and wrote that the "whole of the differential calculus arose originally from the task of drawing tangents through any point on any curve," e.g., an "ellipse." Marx's 1873 letter to Engels shows that Marx started to make use of tangents, curves and ellipses, this time in an economic context. In order to "determine mathematically the principal laws governing crises" one must begin with "calculating these ups and downs," i.e., the "irregular curves" (Marx, 1976b, 82). Therefore it is not surprising that ellipses become a main subject of his "On the Differential" and "Outlines and Excerpts on History of Mathematics and Mechanics from Poppe's Book" in his Mathematical Manuscripts (Marx, 1968, 70, 88-90, 247). This is why I argue that Marx utilized his astronomical-mathematical knowledge for economic-scientific purposes. 


\section{The Argument Reversed}

Despite the evidence presented above, one can still argue that Marx did not intend the "ellipse" figure to mean planetary motion. This is a reasonable objection, because Marx did not make any explicit reference to planetary motion. Therefore I will suppose, for a moment, that he did not intend to refer to planetary curves. Is Marx's description of the ellipse still useful to decide whether planetary motion involves a contradiction? This presupposes an explicit definition of contradiction which Marx, according to Carchedi $(2008,416)$, never provides. So "we should," the argument goes, "extract it from Marx's own work." This brings us back to Carchedi's four principles of dialectics.

If there is a "standard definition" of dialectics or contradiction, then it should be able to encompass all four modes of dialectical contradiction proposed by Carchedi. This means we should seek the most general properties that are common in all four modes of dialectical contradiction. Regarding this generalization, I find the following structure most plausible: all four principles involve one subject (phenomenon) that asserts two opposite predicates (realized/potential, determinant/determined, stability/change, tendency/ counter-tendency). This means that every phenomenon that can satisfy this definition is subject to dialectical contradiction. Although Carchedi would like to have this scheme limited to society, there are natural phenomena that can equally satisfy this definition. Elliptical motion is a good example in this regard.

Marx speaks of an orbital body (subject) that tends to fall into (predicate) and fly away from (opposite predicate) the Sun. This seems to be the reason why Hegel, long before Marx, believed he had found a contradiction in elliptical motion. Engels, on the other hand, says something slightly different from Marx. For Engels (1985, 45), the contradiction is between "attraction" of the Sun and the "tangential force" of the orbit. This means that Engels speaks of two subjects (the Sun and the orbit), and places the contradiction between attraction (predicate) of the Sun and the tangential force (opposite predicate) of the orbit. Either Engels' understanding of the ellipse violates the standard definition which we have developed based on Carchedi's principles, or our definition of dialectics is not general enough to encompass Engels' understanding of dialectical contradictions.

\section{Conclusion}

Marx $(2004,245)$ writes that the capitalist accumulation process necessarily involves "contradictory tendencies" and "contending agencies," and that the 
conflict of contending agencies finds vent in crises. The crises are always but momentary and forcible solutions of the existing contradictions. They are violent eruptions which for a time restore the disturbed equilibrium.

Is this to say that, since planetary motion consists of contradictory tendencies, the destiny of cosmological order will follow the lead of capitalist accumulation? I believe most of Engels' critics, who accuse him of relapsing into positivism, would expect that Engels answers this question affirmatively. Since Marx makes the same analogy between planetary motion and capitalist accumulation, he can be charged with positivism, as well. But this, in turn, is to overlook Marx's (and Engels') original emphasis, or to miss their point: It is the structural identity of existence and development of contradictions that enables us to make comparisons or build analogies between different social and natural phenomena. A discipline like mathematics that applies to both social and natural phenomena is not different from dialectics in this regard. It is therefore inconsistent to dump dialectics of nature, on one side, and insert a dialectical mathematics, on the other. At least for Carchedi, it might be worth reconsidering whether Engels' (1985, 293) definition of dialectics as the "science of universal inter-connection" can promise any fruitful potential for the issue at stake, namely the inter-connection between mathematics and dialectics.

KAAN KANGAL

Center for Studies of Marxist Social Theory

Nanjing University

Xianlin Campus, Qixia District, 38

Nanjing, Jiangsu, 210046

Peoples Republic of China

kaankangal@gmail.com

\section{REFERENCES}

Avineri, Shlomo. 1975. The Social and Political Thought of Karl Marx. London: Cambridge University Press.

Carchedi, Guglielmo. 2008. "Dialectics and Temporality in Marx's Mathematical Manuscripts." Science E Society, 72:4 (October), 415-426.

. 2011. Behind the Crisis: Marx's Dialectics of Value and Knowledge. Leiden, The Netherlands: Brill.

- 2012. "Mathematics and Dialectics in Marx: A Reply." Science E Society, 76:4 (October), 546-549.

Colletti, Lucio. 1973. Marxism and Hegel. London: New Left Books.

Dale, Russell. 2011. "Guglielmo Carchedi on Marx, Calculus, Time and Dialectics." Science E Society, 75:4 (October), 555-566. 
Engels, Friedrich. 1985. Dialektik der Natur. In Karl Marx Friedrich Engels, Gesamtausgabe (MEGA), Vol. I/26.1. Berlin: Dietz.

- 1987a. Dialectics of Nature. Pp. 313-612 in Karl Marx and Frederick Engels, Collected Works, Vol. 25. Moscow: Progress Publishers.

—. 1987b. Engels to Marx, June 16, 1867. Pp. 381-383 in Karl Marx and Frederick Engels, Collected Works, Vol. 42. Moscow: Progress Publishers.

- 1988. Anti-Dühring. In Karl Marx Friedrich Engels, Gesamtausgabe (MEGA), Vol. I/27.1. Berlin: Dietz.

Hegel, G. W. F. 1986. Enzyklopädie der philosophischen Wissenschaften im Grundrisse. 1830. Zweiter Teil. In Hegel, Werke, Vol. 9. Frankfurt a. M., Germany: Suhrkamp.

Helmholtz, Heinz. 1854. Ueber die Wechselwirkung der Naturkräfte und die darauf bezüglichen neuesten Ermittelungen der Physik. Ein populär-wissenschafticher Vortrag gehalten am 7 Februar 1854. Königsberg, Germany: Gräfe.

Jordan, Z. A. 1967. The Evolution of Dialectical Materialism: A Philosophical and Sociological Analysis. New York: St. Martin's Press.

Kaiser, Bruno, and Inge Werchan. 1967. Ex Libris. Karl Marx und Friedrich Engels. Schicksal und Verzeichnis einer Bibliothek. Berlin: Dietz.

Kołakowski, Leszek. 1978. Main Currents of Marxism: Its Rise, Growth, and Dissolution. Volume I: The Founders. Oxford, England: Clarendon Press.

Lichtheim, George. 1972. Europe in the Twentieth Century. New York: Praeger Publishers. Lukács, Georg. 1977. Geschichte und Klassenbewußtsein. In Georg Lukács, Werke, Vol. 2. Neuwied, Germany: Luchterhand.

- 1984. Zur Ontologie des gesellschaftlichen Seins. I. Halbband. In Georg Lukács, Werke, Vol. 13. Neuwied, Germany: Luchterhand.

__ 1998-99. "Chvotismus und Dialektik (1925/26).” Pp. 119-159 in Lukács 1998/99. Jahrbuch der Internationalen Georg-Lukács-Gesellschaft. Paderborn, Germany: Janus-Druck.

Marx, Karl. 1968. Matematicheskie Rukopisi. Moskva: Izdatel'stvo "Nauka”.

. 1975. "Der leitende Artikel in Nr. 179 der 'Kölnischen Zeitung'.” Pp. 172-190 in Karl Marx Friedrich Engels, Gesamtausgabe (MEGA), Vol. I/1.1. Berlin: Dietz. 1976a. Hefte zur epikureischen Philosophie. Fünftes Heft. Pp. 93-118 in Karl Marx Friedrich Engels, Gesamtausgabe (MEGA), Vol. IV/1.1. Berlin: Dietz.

—. 1976b. Marx an Engels, 31 Mai 1873. Pp. 82-84 in Karl Marx Friedrich Engels, Werke (MEW), Vol. 33. Berlin: Dietz.

- 1983. Das Kapital. Kritik der politischen Ökonomie. Erster Band. Hamburg 1867. In Karl Marx Friedrich Engels, Gesamtausgabe (MEGA), Vol. II/5.1. Berlin: Dietz. . 1984. "Revolution in China and in Europe." Pp. 147-153 in Karl Marx Friedrich Engels, Gesamtausgabe (MEGA), Vol. I/12.1. Berlin: Dietz.

. 1987a. Das Kapital. Kritik der politischen Ökonomie. Erster Band. Hamburg 1872.

In Karl Marx Friedrich Engels, Gesamtausgabe (MEGA), Vol. II/6.1. Berlin: Dietz.

— 1987b. Marx to Engels, 19 August 1865. Pp. 183-186 in Karl Marx and Frederick Engels, Collected Works, Vol. 42. Moscow: Progress Publishers.

. 1987c. Marx to Engels, 22 June 1867. Pp. 383-386 in Karl Marx and Frederick Engels, Collected Works, Vol. 42. Moscow: Progress Publishers.

- 1996. Capital: A Critique of Political Economy. Volume I. In Karl Marx and Frederick Engels, Collected Works. Moscow Progress Publishers. 
. 2004. Das Kapital. Kritik der politischen Ökonomie. Dritter Band. Hamburg 1894. In Karl Marx Friedrich Engels, Gesamtausgabe (MEGA), Vol. II/15.1. Berlin: Akademie. Marx, Karl, and Friedrich Engels. 1970. Die Deutsche Ideologie. In Karl Marx Friedrich Engels, Gesamtausgabe $\left(M E G A^{1}\right)$, Vol. I/5. Glashütten im Taunus, Germany: Detlev Auvermann.

Mayer, J. R. 1874. Die Mechanik der Wärme in gesammelten Schriften. Stuttgart, Germany: Cotta.

Sartre, Jean-Paul. 2004. Critique of Dialectical Reason. Volume 1: Theory of Practical Ensembles. London: Verso.

Schmidt, Alfred. 1993. Der Begriff der Natur in der Lehre von Marx. Hamburg, Germany: Europäische Verlagsanstalt.

Thomson, William, and Peter Guthrie Tait. 1872. Treatise on Natural Philosophy. Vol. I. Oxford, England: Clarendon.

Weston, Thomas. 2012. "Marx on the Dialectics of Elliptical Motion." Historical Materialism, 20:4, 3-38. 